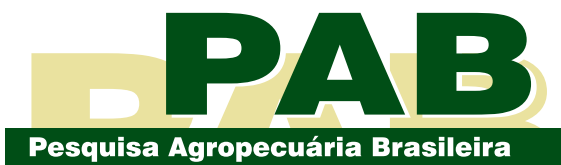

ISSN 1678-3921

Journal homepage: www.embrapa.br/pab

For manuscript submission and journal contents, access: www.scielo.br/pab

\title{
Water-deficit tolerance of landrace and improved corn genotypes
}

\begin{abstract}
The objective of this work was to evaluate the yield, leaf area, stomatal conductance, photosynthesis, transpiration, and critical fraction of transpirable soil water (FTSWc) of hybrid and landrace corn (Zea mays) genotypes, as affected by the water deficit characterized by the FTSW. Two experiments were carried out in the 2015/2016 and 2016/2017 crop years: one in the field and the other in a greenhouse. The following genotypes were evaluated in irrigated and nonirrigated systems: the Cinquentinha and Bico de Ouro landraces and the AS 1573PRO improved cultivar. Yield in the field was higher for 'AS 1573PRO', followed by Bico de Ouro and Cinquentinha in both evaluation years. Water deficit reduces stomatal opening, photosynthesis, and transpiration rate, resulting in the total closure of the stomata of 'AS 1573PRO' and Bico de Ouro, and in the partial closure of those of Cinquentinha. There was a reduction in the leaf area of 'AS 1573PRO', Bico de Ouro, and Cinquentinha under water deficit during the reproductive period. In the first crop year under water deficit conditions, 'AS 1573PRO' and Cinquentinha show a high tolerance to water deficit with a FTSWc of 0.71, and 'AS 1573PRO' also shows the highest tolerance in the second crop year with a FTSWc of 0.73 . Moreover, Bico de Ouro is sensitive to water deficit in the two crop years.
\end{abstract}

Index terms: Zea mays, critical FTSW, genetic variability.

\section{Tolerância ao deficit hídrico de genótipos de milho crioulo e melhorado}

Resumo - O objetivo deste trabalho foi avaliar a produtividade, a área foliar, a condutância estomática, a fotossíntese, a transpiração e a fração de água transpirável no solo crítica (FATSc) de genótipos de milho híbrido e crioulo, em função do deficit hídrico caracterizado pela FATS. Foram realizados dois experimentos, nos anos agrícolas de 2015/2016 e 2016/2017: um a campo e outro em casa de vegetação. Os seguintes genótipos foram avaliados em sistema irrigado e não irrigado: os crioulos Cinquentinha e Bico de Ouro e a cultivar melhorada AS 1573PRO. A produtividade a campo é maior para 'AS 1573PRO', seguida por Bico de Ouro e Cinquentinha, em ambos os anos de avalição. O deficit hídrico reduz a abertura estomática, a fotossíntese e a taxa de transpiração, o que resulta no fechamento total dos estômatos de 'AS 1573PRO' e Bico de Ouro, e no fechamento parcial dos de Cinquentinha. Houve redução da área foliar de 'AS 1573PRO', Bico de Ouro e Cinquentinha sob deficit hídrico durante o período reprodutivo. No primeiro ano agrícola sob condições de deficit hídrico, 'AS 1573PRO' e Cinquentinha mostram alta tolerância ao deficit hídrico com FTSWc de 0,71, e 'AS 1573PRO' também mostra a maior tolerância no segundo ano agrícola com FTSWc de 0,73. Além disso, Bico de Ouro apresenta sensibilidade ao deficit hídrico nos dois anos agrícolas.

Termos para indexação: Zea mays, FATS crítica, variabilidade genética. 


\section{Introduction}

Water deficit (WD) is the main limiting factor for corn (Zea mays L.) growth and yield (Moussa et al., 2019). In the current scenario, in which global average air temperature is increasing, with a foreseen increase in the frequency of extreme events, such as WD (Vicente-Serrano et al., 2020), and the global demand for food is escalating, there is a need for studies to increase crop efficiency. Therefore, understanding the effect of WD on corn and identifying drought-tolerant genotypes is a promising approach to safeguard food supply (Teixeira et al., 2021) and sustainable production (Devi \& Reddy, 2020).

In corn-based cropping systems, farmers use cultivars with different genetic variability, ranging from single-cross hybrids, with a lower variability, to landraces or creole corn races, with a greater variability. Hybrids are used when seeking to obtain high yields and an improved resource efficiency (Galvão et al., 2014), whereas landraces are key to ensure food safety for remote communities (Teixeira et al., 2021). To safeguard food security, any approach to increase production should take into account the socioeconomic and cultural factors affecting producers, aiming to identify genotypes that can be cultivated using less water and nutrients and that have low-costing seeds (Langner et al., 2019).

Water stress reduces the biomass of the roots and aerial part of the corn plant (González-Hernández et al., 2021), and can also delay plant reproductive development (Tardieu et al., 2018) and reduce gas exchange (Santos et al., 2014) and grain yield in up to $59.5 \%$ if WD occurs between the beading and grainfilling stages (Sousa et al., 2015).

To evaluate plant response to $\mathrm{WD}$, the fraction of transpirable soil water (FTSW) has been widely used (Sinclair \& Ludlow,1986; Lago et al., 2012; Sinclair et al., 2018; Devi \& Reddy, 2020). The critical FTSW (FTSWc) indicates the amount of soil water at which stomatal closure begins in response to WD (Sinclair \& Ludlow, 1986; Sinclair et al., 2018). Recent studies have shown that water conservation in different species is associated with partial stomatal closure at higher soil water contents, which normally occurs in most plants, and with a limited transpiration rate under conditions of high evaporative demand (Sinclair et al., 2017). Therefore, more tolerant genotypes could be identified as those that preserve water by limiting transpiration under WD (Devi \& Reddy, 2020), i.e., corn genotypes with a higher FTSWc are more suitable for a longer soil WD (Sinclair et al., 2018).

In the literature, some studies have compared the effect of WD on landrace and improved corn genotypes. González-Hernández et al. (2021), for example, assessing 48 improved and landrace genotypes, identified 2 landraces as the most tolerant to WD at the seedling stage. When evaluating 2 landraces and 2 hybrid genotypes in a controlled environment, Mazvimbakupa et al. (2015) concluded that landraces can have a performance similar to that of the hybrids under severe water stress. In this context, the prolificity of traditional varieties can compensate for yield and can be used in marginal regions due to their food safety potential.

The objective of this work was to evaluate the yield, leaf area, stomatal conductance, photosynthesis, transpiration, and FTSWc of hybrid and landrace corn genotypes, as affected by the WD characterized by the FTSW.

\section{Materials and Methods}

Experiments were conducted in the field and in pots in a greenhouse, in the 2015/2016 and 2016/2017 crop years, in the municipality of Santa Maria, in the state of Rio Grande do Sul, Brazil (29 $43^{\circ} \mathrm{S}, 53^{\circ} 43^{\prime} \mathrm{W}$, at an altitude of $95 \mathrm{~m}$ ). The climate of the region is humid temperate, classified as Cfa by Köppen-Geiger, with a hot summer, abundant and well-distributed rainfall throughout the year, and average temperature of the hottest month of $22^{\circ} \mathrm{C}$ or higher. The soil of the experimental site is an Argissolo Vermelho distrófico (Santos et al., 2018), i.e., a Rhodic Paleudalf (Ultisol).

In the field, the experimental design was a twofactor randomized complete block, with four and three replicates, respectively, in the 2015/2016 and 2016/2017 crop years (EI and EII, respectively); each replicate was a plot with $5.0 \mathrm{~m}$ length rows. Factor A was three genotypes: two landraces, Cinquentinha and Bico de Ouro, of early and late maturity, respectively; and the single-cross hybrid, 'AS 1573PRO', of early maturity. Factor B was soil water management (rainfed or irrigated). Soil correction and fertilization were carried out according to the following results of the soil analysis: $1.4 \%$ organic matter, $340 \mathrm{~g} \mathrm{~kg}^{-1}$ clay, cation exchange capacity of $12.8 \mathrm{cmol}_{\mathrm{c}} \mathrm{dm}^{-3}, \mathrm{pH} \mathrm{7,}$ 
$16 \mathrm{mg} \mathrm{dm}^{-3}$ potassium, $4.7 \mathrm{mg} \mathrm{dm}^{-3}$ phosphorus, lime requirement of 5.4 by the Shoemaker-McLean-Pratt test, aluminum saturation of $21.2 \%$, aluminum content of $1.1 \mathrm{cmol}_{\mathrm{c}} \mathrm{dm}^{-3}, 3.2 \mathrm{cmol}_{\mathrm{c}} \mathrm{dm}^{-3}$ calcium, and 0.8 $\mathrm{cmol}_{\mathrm{c}} \mathrm{dm}^{-3}$ magnesium (Manual..., 2016).

The row spacing was $1.0 \mathrm{~m}$ in the plots with the landraces and $0.5 \mathrm{~m}$ in the plots with the hybrid, with a plant density of 6.0 plants per square meter for both genotype groups. The different line spacing was used to adapt the plants to a condition close to the one in which they are cultivated by farmers. After plant emergence, 30 and 10 plants per plot with landraces and the hybrid, respectively, were tagged and used to measure growth and development variables throughout the crop year.

For all genotypes, sowing dates were on 10/23/2015 and 10/29/2016 in EI and EII, respectively. However, when plants were between the V5-V6 vegetative growth stages in EII, leaf spots occurred, requiring another sowing to be carried out on 12/21/2016 for Bico de Ouro and on 12/28/2016 for 'AS 1573PRO' and Cinquentinha. Since Bico de Ouro is a late-maturing genotype, its sowing was anticipated for the silking dates of all genotypes to be synchronized.

For water management, water soil balance was calculated daily. Reference evapotranspiration (millimeter per day) was estimated by the PenmanMonteith equation. Meteorological variables were collected from an automatic meteorological station belonging to Instituto Nacional de Meteorologia, located approximately $100 \mathrm{~m}$ from the experimental area. Using drip hoses placed along the plant row, a supplementary irrigation of $20 \mathrm{~mm}$ was performed whenever crop evapotranspiration accumulated values of $20 \mathrm{~mm}$, in order to maintain soil water content above $75 \%$ available water capacity ( $140 \mathrm{~mm}$ up to $1.0 \mathrm{~m}$ in the soil profile).

For grain yield determination, ears of the tagged plants were harvested when the R6 stage was completed, and the number of ears per plant, number of grains per ear, and average dry mass of 100 grains were measured. Yield data from the field experiment were subjected to the analysis of variance (Anova), and means were compared by Tukey's test, at 5\% probability, using the Sisvar software (Ferreira, 2011).

A pot experiment was carried out to determine the FTSW. Corn plants were grown in $9.0 \mathrm{~L}$ plastic pots with the outer wall painted white to reduce solar radiation absorption and arranged in a structure covered with $200 \mu \mathrm{m}$ low density polyethylene to prevent rainfall on plants. The pots were filled with an "A" horizon layer of soil collected near the site of the field experiment and then placed on a raised bench with a height of about $20 \mathrm{~cm}$, to keep the roots from reaching the ground. Soil correction and fertilization were performed according to the soil analysis for the field experiment (Manual..., 2016).

The experimental design was completely randomized with two water regimes: without WD (T1) and with WD (T2), with ten replicates of one pot with one plant each; the plants were subjected to WR in the tasseling stage (VT). The sowing dates in the 2016/2017 crop year were the same for the experiments in the greenhouse and in the field: 12/21/2016 for Bico de Ouro and 12/28/2016 for 'AS 1573PRO' and Cinquentinha. In 2017/2018, however, sowing in the pots was carried out on 9/28/2017 for Bico de Ouro and on 5/10/2017 for 'AS 1573PRO' and Cinquentinha.

Before WD application, pots were watered until saturation, for 24 hours, using buckets. The soil surface in the pots was covered with a $200 \mu \mathrm{m}$ white-opaque plastic film to minimize soil water evaporation. After a 24 hour saturation period, pots were left to drain for 4 hours, for the soil to reach field capacity, when the initial weight of each pot was determined.

Pots were weighed daily at 4 p.m. on a scale with 5.0 $\mathrm{g}$ precision and $50 \mathrm{~kg}$ weight capacity. After weighing, the water transpired in T1 was fully replaced for half of the plants of each genotype (10 pots), but only replaced in $50 \%$ for the other half, which was kept under WD (T2). The relative transpiration (RT), which represents the daily transpiration of plants under WD compared with those without WD (maximum transpiration), was calculated every day according to the methodology of Sinclair \& Ludlow (1986): RT = Water loss by T2 plants (each plot) / Daily average loss of T1 plants. The experiment ended when the RT of the plants under WD reached $10 \%$ of the RT of the plants without WD $(\mathrm{RT} \leq$ $0.1)$. The plants were subjected to WD from $2 / 22 / 2017$ to $3 / 7 / 2017$ (15 days) in EI and from $12 / 12 / 2017$ to 12/22/2017 (10 days) in EII.

After the end of each experiment, the FTSW was calculated according to the methodology proposed by Sinclair \& Ludlow (1986). The FTSW was determined daily for each pot of T2 by: FTSW = (mass of each pot each day - final mass) / (initial mass - final mass). The RT data were normalized twice. The first RT 
normalization was set between 0 and 1 , whereas the second (NRT, normalized relative transpiration) was done to reduce variation among plants by dividing the RT of each plant by the mean RT with a FTSW equal to or greater than 0.60 (Sinclair \& Ludlow, 1986).

The NRT data were plotted as a function of the FTSW, and a logistic equation was fitted (Sinclair \& Ludlow, 1986): $\mathrm{y}=1 /\{1+\exp [-\mathrm{a}(\mathrm{x}-\mathrm{b})]\}$, where $\mathrm{y}$ is the dependent variable (NRT), $x$ is the FTSW, and a and $b$ are empirical coefficients that were determined by a nonlinear regression using the SAS software (SAS Institute Inc., Cary, NC, USA). The FTSWc values were obtained for an NRT of 0.95 (Lago et al., 2012).

To calculate leaf area (LA, $\mathrm{cm}^{2}$ ) during the experiment, green leaf length $(\mathrm{cm})$ and width $(\mathrm{cm})$ were measured daily in EI or every 3 days in EII, using equations with the following shape coefficients: $\mathrm{LA}=0.7752 \times(\mathrm{LW})$ for Cinquentinha, $\mathrm{LA}=0.7881 \times(\mathrm{LW})$ for Bico de Ouro, and LA $=0.7621 \times(\mathrm{LW})$ for 'AS 1573PRO'. The shape coefficients were estimated from a field experiment conducted in the 2014/2015 and 2015/2016 crop years in the municipality of Santa Maria. A total of 70 leaves of each genotype were digitalized and then their area was measured by the Quant software, version 1.0.1 (Vale et al., 2001), and compared with the leaf area estimated by the LW multiplication. To validate the equations, independent data from 45 leaves per genotype were used and evaluated using the goodness of fit standards root mean squared error (RMSE) and mean absolute error (MAE). Linear equations presented the following RMSE and MAE, respectively: 67.49 and $54.56 \mathrm{~cm}^{2}$ per leaf for Cinquentinha, 51.80 and $38.37 \mathrm{~cm}^{2}$ per leaf for Bico de Ouro, and 23.12 and $19.07 \mathrm{~cm}^{2}$ per leaf for 'AS 1573PRO'.

Gas exchange was measured in four plants of each treatment between 12 p.m. and 2 p.m. during the WD period using the LCi-SD portable photosynthesis system (ADC BioScientific Ltd., Hoddesdon, UK). Stomatal conductance $\left(\mathrm{mol} \mathrm{H}_{2} \mathrm{O} \mathrm{m}^{-2} \mathrm{~s}^{-1}\right)$, photosynthesis rate $\left(\mu \mathrm{mol} \mathrm{CO} \mathrm{C}^{-2} \mathrm{~s}^{-1}\right)$, and transpiration rate $(\mathrm{mol} \mathrm{H}$ $\left.\mathrm{m}^{-2} \mathrm{~s}^{-1}\right)$ were also measured on the last expanded leaf exposed to sunlight.

\section{Results and Discussion}

In the field experiment, precipitation was well distributed during the vegetative phase of the plants in both EI and EII (Figure 1). However, in EI, a supplementary irrigation was required in the reproductive phase, from $1 / 4 / 2016$ to $1 / 24 / 2016$, in the irrigated treatment. During this period, the plants of Bico de Ouro were completing the silking and grainfilling stages, and those of Cinquentinha and 'AS 1573PRO' had started the grain-filling stage. In EII, a supplementary irrigation was necessary from 3/3/2017 to $4 / 17 / 2017$, also in the irrigated treatment.

The Anova for the field experiment indicated that the cultivar $\mathrm{x}$ soil water management interaction was not significant, although individual factors showed significance; therefore, it was not possible to analyze the response of the cultivar to WD using this parameter.

Regarding grain yield, in both EI and EII, the values obtained for the landraces were lower than that of the 'AS 1573PRO' hybrid (Table 1). However, no differences were observed in grain yield for the factor soil water management, contrary to the data in the literature that showed a decrease in corn yield under WD in the reproductive phase (Sousa et al., 2015).

In EII, the mean grain yield was higher than that of the previous year, except for Cinquentinha (Table 1). Since the Bico de Ouro landrace showed an increased yield in this crop year, when a second sowing was carried out and more fertilizer was added to the soil, this genotype is likely more responsive to technological inputs. Cinquentinha presented similar yields of 6.3 and $6.8 \mathrm{Mg} \mathrm{ha}^{-1}$ under the different water management conditions, indicating that it is part of the landrace genotypes that can keep profitable yields in systems with a low technological level (Silveira et al., 2015). Landrace genotypes show a greater genetic diversity in response to fertilizer rates and are sources of genes that tolerate low fertilization, even of phosphorus (Spolaor et al., 2018).

Gas exchange measurements indicated a reduction in stomatal opening, photosynthesis, and transpiration rate on 2/25/2017 during EI. On the second day of WD, stomata were closed to reduce transpiration, which affected photosynthesis (Figure 2). Two days later, on $2 / 27 / 2017$, the stomata of all genotypes had already been closed, except those of Cinquentinha, which remained open until 2/28/2017, with reductions in the transpiration and photosynthesis rates. In the second crop year, the values for stomatal conductance, transpiration rate, and photosynthesis started to reduce on the second day of the WD period, reaching zero in

Pesq. agropec. bras., Brasília, v.56, e02627, 2021

DOI: 10.1590/S1678-3921.pab2021.v56.02627 
the plants of 'AS 1573PRO' on the third day, but being higher and intermediate for Cinquentinha and Bico de Ouro, respectively. When evaluating sweet corn at different irrigation depths, Brito et al. (2013) observed a photosynthesis rate of around $15.00 \mu \mathrm{mol} \mathrm{CO}_{2} \mathrm{~m}^{-2} \mathrm{~s}^{-1}$, stomatal conductance of $0.16 \mathrm{~mol} \mathrm{H}_{2} \mathrm{O} \mathrm{m} \mathrm{m}^{-2} \mathrm{~s}^{-1}$, and transpiration of $2.80 \mathrm{~mol} \mathrm{H}_{2} \mathrm{O} \mathrm{m} \mathrm{m} \mathrm{s}^{-1}$ at 90 days after sowing. For corn under water stress, Santos et al.
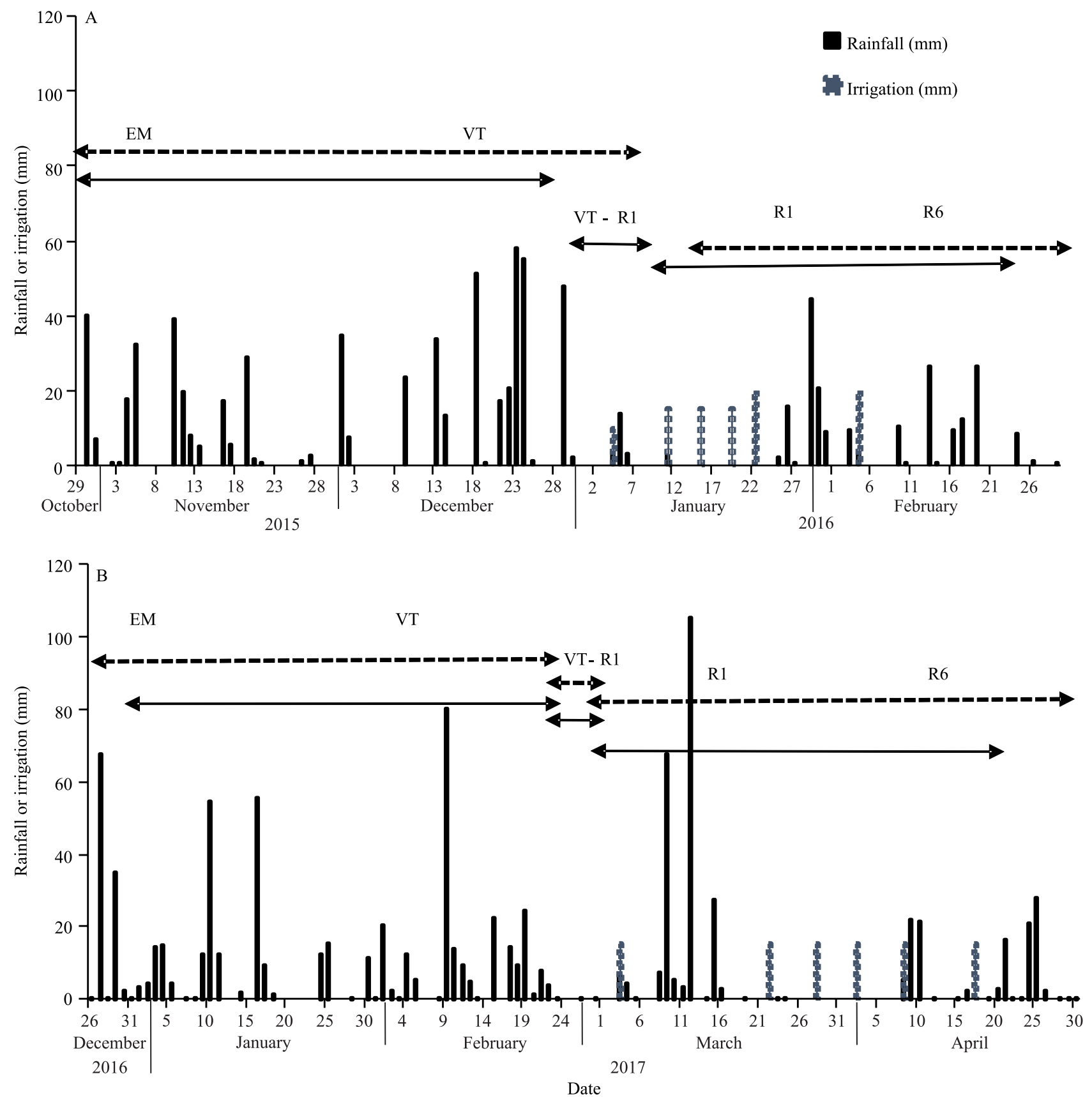

Figure 1. Daily rainfall data collected from an automatic meteorological station, located approximately $100 \mathrm{~m}$ from the experimental site, and irrigation management in the municipality of Santa Maria, in the state of Rio Grande do Sul, Brazil, during the 2015/2016 (A) and 2016/2017 (B) crop years of the 'AS 1573PRO', Bico de Ouro, and Cinquentinha corn (Zea mays) genotypes. The dashed-arrow lines represent the average length of the development stages from emergence to tasseling (EM-VT), tasseling to silking (VT-R1), and silking to physiological maturity (R1-R6). Full-arrow lines represent the early maturing genotypes, 'AS 1573PRO' and Cinquentinha. 
(2014) reported reductions, in the morning and in the afternoon, respectively, of 53 and $66 \%$ in photosynthesis rate, of 87 and $89 \%$ in stomatal conductance, and of 84 and $86 \%$ in transpiration rate at 69 days after emergence; these values are lower than those found in the present study. Gas exchange reduction, especially stomatal conductance, is one of the first responses of plants under low water availability to minimize leaf water loss (Taiz \& Zeiger, 2013). The Cinquentinha landrace maintained low gas exchange rates for more days than the other genotypes, which indicates that it may be more tolerant to WD. During periods of water stress, the growth of a plant depends on its ability to preserve cell turgor, in which the perception of WD is likely to involve osmotic sensors (Taiz \& Zeiger, 2013).

The green area of all leaves measured daily showed a reduction, or senescence, in the plants under WD (Figure 3). In EI, leaf senescence began on 2/27/2017 and 2/28/2017 for plants of Bico de Ouro and Cinquentinha, respectively, but only on 3/1/2017 for plants of 'AS 1573PRO'. In EII, green leaf area started to reduce on 12/15/2017 for Cinquentinha and Bico de Ouro plants, but on 12/17/2017 for 'AS 1573PRO' plants. In plants not subjected to $\mathrm{WD}$, the green leaf area increased but remained close to the initial one due to the advanced development stage in both experimental years.

The FTSWc values indicated that, in the first crop year, plants of 'AS 1573PRO' and Cinquentinha had a similar tolerance to WD because they closed their stomata earlier, and that, in the second year, plants of 'AS 1573PRO' were more tolerant (Figure 4). However, despite stomatal closure, gas exchange measurements showed that the studied rates were not reduced completely in plants of Cinquentinha, which kept a small stomatal opening, allowing transpiration and photosynthesis to continue. Therefore, two plants of this genotype, even under WD, completed the reproductive phase and produced ears with grains. The FTSWc values found in the present study are higher than those reported in the literature, which can be attributed to the different development stages of the evaluated plants - more advanced (with maximum leaf area) vs vegetative stage. Gholipoor et al. (2013) found a FTSWc ranging from 0.33 to 0.60 for hybrids 20 days after sowing, whereas Romdhane et al. (2019) obtained a FTSWc of 0.817 for a tolerant hybrid and of 0.460 for a drought-sensitive hybrid in V4. Analyzing 8 leaves of 4 genotypes under WD in the vegetative stage, Moussa et al. (2019) reported a FTSWc varying from 0.495 to 0.671 for plants irrigated daily and from 0.265 to 0.550 for plants irrigated every 3 days. In another study also using plants in the early vegetative period, FTSWc ranged from 0.37 to 0.59 under moderate vapor-pressure deficit and from 0.50 to 0.64 under high deficit at 30 days after sowing (Choudhary et al., 2020). At 20-25 days after sowing, limits of 0.42 to 0.51 were obtained for a corn hybrid, being higher under a greater evaporative atmospheric demand (Devi \& Reddy, 2020). High FTSWc values in the reproductive period may be related to the high water demand of the plants, as observed for gladiolus (Becker et al., 2021).

The high values of FTSWc reported in the mentioned studies, except that of 0.817 found by Romdhane et al. (2019), are considered an advantage because, in soils with a low water content, early stomata closure allows water conservation in the soil, being an adaptive criterion of the corn species (Gholipoor et al., 2013; Sinclair et al., 2018). This shows the need for further

Table 1. Average grain yield of three corn (Zea mays) genotypes in the 2015/2016 and 2016/2017 crop years, in a field experiment, under irrigated and nonirrigated management systems, in the municipality of Santa Maria, in the state of Rio Grande do Sul, Brazil ${ }^{(1)}$.

\begin{tabular}{|c|c|c|c|c|c|c|}
\hline \multirow[t]{2}{*}{ Genotype } & \multicolumn{3}{|c|}{ Grain yield in $2015 / 2016\left(\mathrm{Mg} \mathrm{ha}^{-1}\right)$} & \multicolumn{3}{|c|}{ Grain yield in 2016/2017 $\left(\mathrm{Mg} \mathrm{ha}^{-1}\right)$} \\
\hline & Irrigated & Nonirrigated & Mean & Irrigated & Nonirrigated & Mean \\
\hline 'AS 1573PRO' & 11.7 & 10.5 & $11.1 \mathrm{a}$ & 12.7 & 12.1 & $12.4 \mathrm{a}$ \\
\hline Bico de Ouro & 8.8 & 8.5 & $8.7 \mathrm{~b}$ & 10.6 & 9.5 & $10.0 \mathrm{~b}$ \\
\hline Cinquentinha & 6.5 & 6.3 & $6.4 \mathrm{c}$ & 6.5 & 6.8 & $6.7 \mathrm{c}$ \\
\hline Mean & $9.0 \mathrm{~A}$ & $8.4 \mathrm{~A}$ & & $9.9 \mathrm{~A}$ & $9.5 \mathrm{~A}$ & \\
\hline
\end{tabular}

${ }^{(1)}$ Means followed by equal letters, lowercase in the columns and uppercase in the rows, within the experiments, do not differ by Tukey's test, at $5 \%$ probability.

Pesq. agropec. bras., Brasília, v.56, e02627, 2021

DOI: 10.1590/S1678-3921.pab2021.v56.02627 

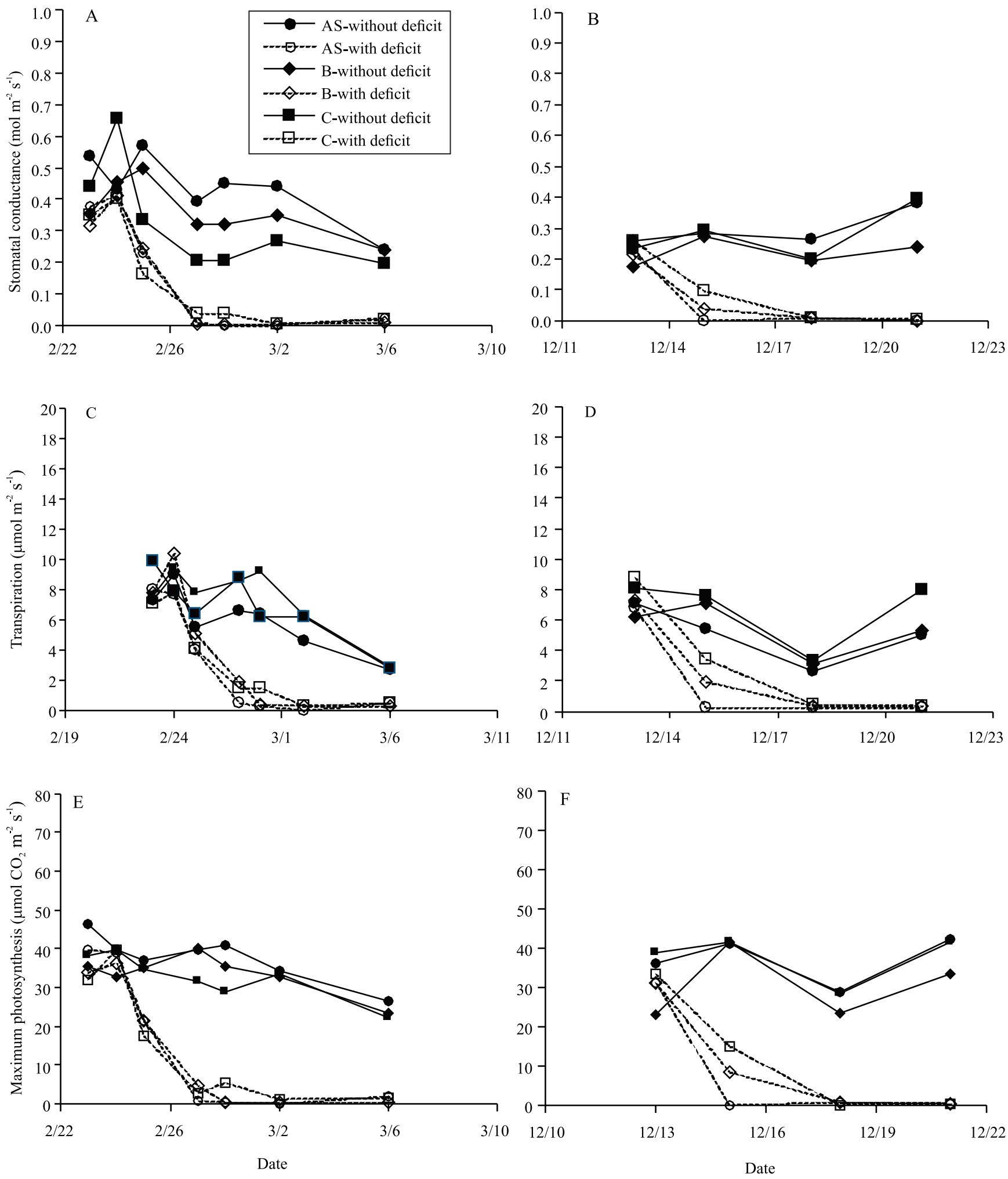

Figure 2. Stomatal conductance (A and B), transpiration (C and D), and maximum photosynthesis (E and F) for three corn (Zea mays) genotypes - 'AS 1573PRO' (AS - with and without deficit), Bico de Ouro (B - with and without deficit), and Cinquentinha (C - with and without deficit) - during the water deficit period from 2/22/2017 to 3/7/2017 (A, C, and E) and from $12 / 12 / 2017$ to $12 / 21 / 2017$ (B, D, and F), in the municipality of Santa Maria, in the state of Rio Grande do Sul, Brazil. 

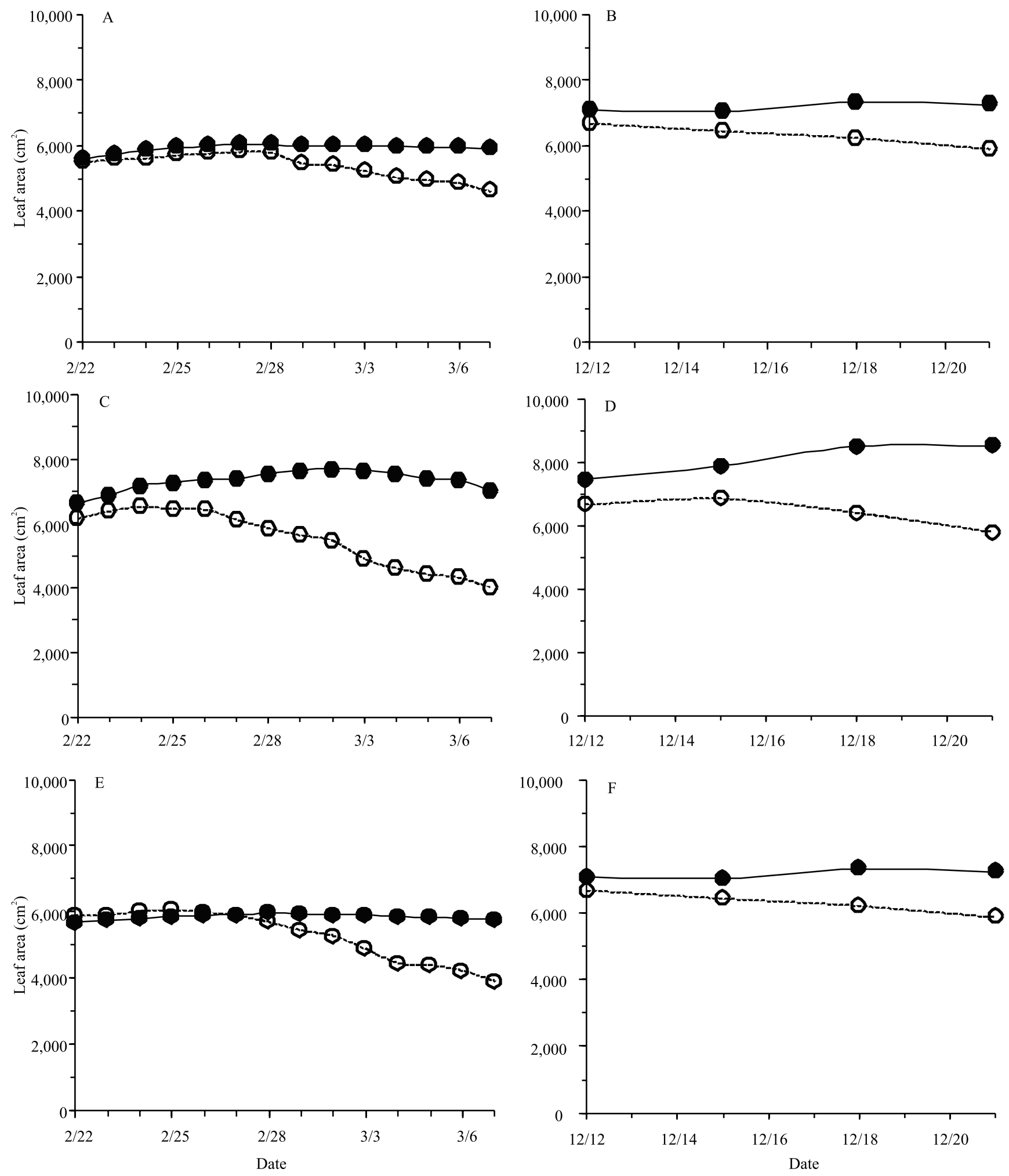

Figure 3. Leaf area of the 'AS 1573PRO' (A and B), Bico de Ouro (C and D), and Cinquentinha (E and F) corn (Zea mays) genotypes measured during the water deficit period from 2/22/2017 to 3/7/2017 (A, C, and E) and from 12/12/2017 to 12/21/2017 (B, D, and F), in the municipality of Santa Maria, in the state of Rio Grande do Sul, Brazil. Solid circles represent no water deficit, and opened circles, water deficit. 

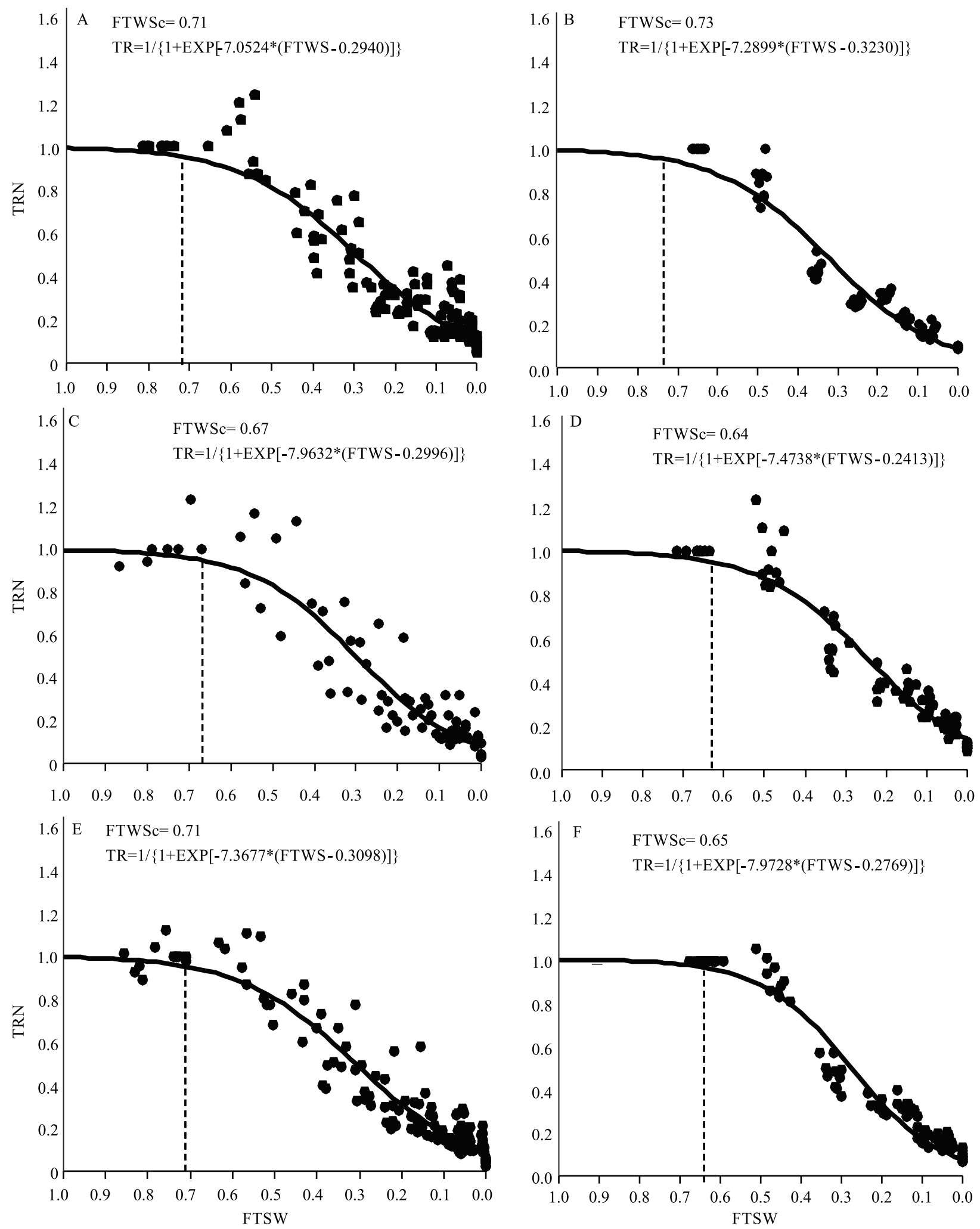

Figure 4. Normalized relative transpiration (NRT) as a function of the fraction of transpirable soil water (FTSW) for the 'AS 1573PRO' (A and B), Bico de Ouro (C and D), and Cinquentinha (E and F) corn (Zea mays) genotypes during the water deficit period from 2/22/2017 to 3/7/2017 (A, C, and E) and from 12/12/2017 to 12/21/2017 (B, D, and F), in the municipality of Santa Maria, in the state of Rio Grande do Sul, Brazil. FTSWc, critical fraction of transpirable soil water. 
studies on the reproductive phase of corn under different evaporative atmospheric demands.

The results of the present study are indicative that the Cinquentinha landrace has a lower grain yield in the field and a greater tolerance to WD due to a more efficient stomatal control, leading to a higher threshold FTSW under a low soil water content. Therefore, this genotype can be recommended for smallholder farmers with low technological inputs, including WD. However, the 'AS 1573PRO' hybrid presented a higher grain yield in the field and a greater tolerance to WD because of early stomatal closure under water shortage, being indicated for farmers who invest in high technology systems.

\section{Conclusions}

1. In the field experiment, yield is higher for the AS 1573PRO corn (Zea mays) cultivar, followed by the Bico de Ouro and Cinquentinha landraces in the 2015/2016 and 2016/2017 crop years.

2. Water deficit (WD) reduces stomatal opening, photosynthesis rate, and transpiration rate, resulting in the total closure of the stomata of 'AS 1573PRO' and Bico de Ouro and in the partial closure of the stomata of Cinquentinha.

3. 'AS 1573PRO', Bico de Ouro, and Cinquentinha show a reduction in green leaf area when subjected to WD in the reproductive period.

4. Under WD conditions in the first crop year, 'AS 1573PRO' and Cinquentinha show a high tolerance to WD with a critical fraction of transpirable soil water (FTSWc) of 0.71.

5. 'AS 1573PRO' also shows the highest tolerance under WD in the second crop year with a FTSWc of 0.73, while Bico de Ouro shows sensitivity to WD in both years.

\section{Acknowledgments}

To Coordenação de Aperfeiçoamento de Pessoal de Nível Superior (Capes), for finalcial support (Finance Code 001, process number 164636/2015-3).

\section{References}

BECKER, C.C.; STRECK, N.A.; GUBIANI, P.I.; UHLMANN, L.O.; LANGNER, J.A.; TOMIOZZO, R.; BALEST, D.S.; PETRY, M.T. Transpiration and leaf growth of gladiolus in response to soil water deficit. Scientia Horticulturae, v.283, art.110031, 2021. DOI: https://doi.org/10.1016/j.scienta.2021.110031.

BRITO, M.E.B.; ARAÚJO FILHO, G.D. de; WANDERLEY, J.A.C.; MELO, A.S. de; COSTA, F.B. da; FERREIRA, M.G.P. Crescimento, fisiologia e produção do milho doce sob estresse hídrico. Bioscience Journal, v.29, p.1244-1254, 2013.

CHOUDHARY, S.; GUHA, A.; KHOLOVA, J.; PANDRAVADA, A.; MESSINA, C.D.; COOPER, M.; VADEZ, V. Maize, sorghum, and pearl millet have highly contrasting species strategies to adapt to water stress and climate change-like conditions. Plant Science, v.295, art.110297, 2020. DOI: https://doi.org/10.1016/j. plantsci.2019.110297.

DEVI, M.J.; REDDY, V.R. Stomatal closure response to soil drying at different vapor pressure deficit conditions in maize. Plant Physiology and Biochemistry, v.154, p.714-722, 2020. DOI: https://doi.org/10.1016/j.plaphy.2020.07.023.

FERREIRA, D.F. Sisvar: a computer statistical analysis system. Ciência e Agrotecnologia, v.35, p.1039-1042, 2011. DOI: https://doi.org/10.1590/S1413-70542011000600001.

GALVÃO, J.C.C.; MIRANDA, G.V.; TROGELlO, E.; FRITSCHE-NETO, R. Sete décadas de evolução do sistema produtivo da cultura do milho. Revista Ceres, v.61, p.819828, 2014. Suplemento. DOI: https://doi.org/10.1590/0034$737 \mathrm{x} 201461000007$.

GHOLIPOOR, M.; SINCLAIR, T.R.; RAZA, M.A.S.; LÖFFLER, C.; COOPER, M.; MESSINA, C.D. Maize hybrid variability for transpiration decrease with progressive soil drying. Journal of Agronomy and Crop Science, v.199, p.23-29, 2013. DOI: https://doi.org/10.1111/j.1439-037X.2012.00530.x.

GONZÁLEZ-HERNÁNDEZ, V.A.; LUGO-CRUZ, E.; MENDOZA-ONOFRE, L.E.; SANTACRUZ-VARELA, A.; GUTIÉRREZ-ESPINOSA, A.; ZAVALA-GARCÍA, F. Maize (Zea mays L.) landraces classified by drought stress tolerance at the seedling stage. Emirates Journal of Food and Agriculture, v.33, p.29-36, 2021.

LAGO, I; STRECK, N.A.; ZANON, A.J.; HANAUER, J.G.; BISOGNIN, D.A.; SLVA, M.R. da. Transpiração e crescimento foliar de clones de batata em resposta à fração de água transpirável no solo. Revista Brasileira de Ciências do Solo, v.36, p.745-754, 2012. DOI: https://doi.org/10.1590/S0100-06832012000300006.

LANGNER, J.A.; ZANON, A.J.; STRECK, N.A.; REINIGER, L.R.S.; KAUFMANN, M.P.; ALVES, A.F. Maize: key agricultural crop in food security and sovereignty in a future with water scarcity. Revista Brasileira de Engenharia Agrícola e Ambiental, v.23, p.648-654, 2019. DOI: https://doi.org/10.1590/1807-1929/agriambi.v23n9p648-654.

MANUAL de calagem e adubação para os estados do Rio Grande do Sul e de Santa Catarina. 11.ed. Porto Alegre: Sociedade Brasileira de Ciência do Solo, Núcleo Regional Sul, Comissão de Química e Fertilidade do Solo - RS/SC, 2016. 376p.

MAZVIMBAKUPA, F.; MODI, A.T.; MABHAUDHI, T. Seed quality and water use characteristics of maize landraces compared with selected commercial hybrids. Chilean Journal of Agricultural Research, v.75, p.13-20, 2015. DOI: https://doi.org/10.4067/S0718-58392015000100002. 
MOUSSA, O.A.; BOUREIMA, S.; ISSOUFOU, H.B.-A.; BAKASSO, Y.; MAHAMANE, A.; SAADOU, M.; ZAMANALLAH, M. Response of maize (Zea mays L.) hybrids to diurnal variation of vapor pressure deficit (VPD) and progressive soil moisture depletion. Journal of Plant Sciences, v.7, p.1-7, 2019.

ROMDHANE, L.; AWAD, Y.M.; RADHOUANE, L.; DAL CORTIVO, C.; BARION, G.; PANOZZO, A.; VAMERALI, T. Wood biochar produces different rates of root growth and transpiration in two maize hybrids (Zea mays L.) under drought stress. Archives of Agronomy and Soil Science, v.65, p.846-866, 2019. DOI: https://doi.org/10.1080/03650340.2018.1532567.

SANTOS, H.G. dos; JACOMINE, P.K.T.; ANJOS, L.H.C. dos; OLIVEIRA, V.Á. de; LUMBRERAS, J.F.; COELHO, M.R.; ALMEIDA, J.A. de; ARAÚJO FILHO, J.C. de; OLIVEIRA, J.B. de; CUNHA, T.J.F. Sistema brasileiro de classificação de solos. 5.ed. rev. e ampl. Brasília: Embrapa, 2018. 356p.

SANTOS, O.O.; FALCÃO, H.; ANTONINO, A.C.D.; LIMA, J.R.S.; LUSTOSA, B.M.; SANTOS, M.G. Desempenho ecofisiológico de milho, sorgo e braquiária sob déficit hídrico e reidratação. Bragantia, v.73, p.203-212, 2014. DOI: https://doi.org/10.1590/brag.2014.018.

SILVEIRA, D.C.; BONETTI, L.P.; TRAGNAGO, J.L.; NETO, N. Produtividade e características de variedades de milho crioulo cultivadas na Região Noroeste do Rio Grande do Sul. Agrarian Academy, v.2, p.60-69, 2015. DOI: https://doi.org/10.18677/ Agrarian_Academy_018.

SINCLAIR, T.R.; DEVI, J.; SHEKOOFA, A.; CHOUDHARY, S.; SADOK, W.; VADEZ, V.; RIAR, M.; RUFTY, T. Limitedtranspiration response to high vapor pressure deficit in crop species. Plant Science, v.260, p.109-118, 2017. DOI: https://doi.org/10.1016/j.plantsci.2017.04.007.

SINCLAIR, T.R.; LUDLOW, M.M. Influence of soil water supply on the plant water balance of four tropical grain legumes. Australian Journal of Plant Physiology, v.13, p.329-341, 1986. DOI: https://doi.org/10.1071/PP9860329.
SINCLAIR, T.R.; SHEKOOFA, A.; ISLEIB, T.G.; BALOTA, M.; ZHANG, H. Identification of Virginia-type peanut genotypes for water-deficit conditions based on early decrease in transpiration rate with soil drying. Crop Science, v.58, p.2607-2612, 2018. DOI: https://doi.org/10.2135/cropsci2018.05.0293.

SOUSA, R.S. de; BASTOS, E.A.; CARDOSO, M.J.; RIBEIRO, V.Q.; BRITO, R.R. de. Desempenho produtivo de genótipos de milho sob déficit hídrico. Revista Brasileira de Milho e Sorgo, v.14, p.49-60, 2015. DOI: https://doi.org/10.18512/1980-6477/ rbms.v14n1p49-60.

SPOLAOR, L.T.; GUIRADO, G.C.; SCAPIM, C.A.; KUKI, M.C.; BERTAGNA, F.A.B.; FERREIRA, J.M.; ZUCARELI, C.; GONÇALVES, L.S.A. Brazilian maize landraces variability under high and low phosphorus inputs. Maydica, v.63, art.M10, 2018.

TAIZ, L.; ZEIGER, E. Fisiologia vegetal. 5.ed. Porto Alegre: Artmed, 2013. 918p.

TARDIEU, F.; SIMONNEAU, T.; MULLER, B. The physiological basis of drought tolerance in crop plants: a scenario-dependent probabilistic approach. Annual Review of Plant Biology, v.69, p.733-759, 2018. DOI: https://doi.org/10.1146/annurevarplant-042817-040218.

TEIXEIRA, M.; FEIJÃO, E.; CATARINO, L.; MATOS, A.R.; FIGUEIREDO, A.; MARQUES DA SILVA, J. Exploring local maize diversity for increased agricultural sustainability: new insights into drought stress response and recovery of GuineaBissau landraces. Sustainability, v.13, art.5441, 2021. DOI: https://doi.org/10.3390/su13105441.

VALE, F.X.R.; FERNANDES FILHO, E.I.; LIBERATO, J.R. Quantificação de doenças - Quant: versão 1.0.1. Viçosa: UFV, 2001. Software.

VICENTE-SERRANO, S.M.; QUIRING, S.M.; PEÑAGALLARDO, M.; YUAN, S.; DOMÍNGUEZ-CASTRO, F. A review of environmental droughts: increased risk under global warming? Earth-Science Reviews, v.201, art.102953, 2020. DOI: https://doi.org/10.1016/j.earscirev.2019.102953. 